\title{
ANALISIS PERKEMBANGAN EMOSIONAL ANAK BERKEBUTUHN KHUSUS HIPERAKTIF DAN GANGGUAN KONSENTRASI DI TK AISYIYAH 33 SURABAYA
}

\author{
Isroun Nissa \\ TK Aisyiyah 33 Surabaya \\ Email: isroun.nissa-2014@ fkip.um-surabaya.ac.id ${ }^{1}$
}

\begin{abstract}
ABSTRAK
Perkembangan emosional anak berkebutuhan khusus hiperaktif dan gangguan konsentrasi adalah gangguan yang terjadi pada anak usia dini yang berpengaruh pada kesulitan dalam proses pembelajaran saat di kelas. Perkembangan emosional sangat berkaitan dengan gangguan ini karena emosi dalam diri anak tidak dapat dikendalikan. Stimulus yang positif harus ditanamkan agar anak dapat memahami konsep diri. Rumusan masalah dalam penelitian ini adalah perkembangan anak berkebutuhan khusus hiperaktif dan gangguan konsentrasi di TK Aisyiyah 33 Surabaya. Penelitian ini bertujuan untuk menggambarkan aspek perkembangan terutama aspek emosional anak. Metode yang digunakan dalam penelitian ini adalah metode kualitatif berupa deskriptif yang berisi katakata dalam deskriptif. Teknik pengumpulan data menggunakan observasi, wawancara dan dokumentasi. Objek penelitiannya adalah anak berkebutuhan khusus hiperaktif dan gangguan konsentrasi (ADHD). Hasil penelitian dapat ditemukan perkembangan emosional anak mempengaruhi kondisi anak berkebutuhan khusus hiperaktif dan gangguan konsentrasi (ADHD), sehingga anak kurang memahami emosi dalam diri seperti menunjukkan ekspresi bahagia, kemrahan dan kekecewaan yang berlebihan. Hal ini yang di latar belakangi oleh beberapa faktor yang ditemukan yaitu faktor kematangan, pola asuh, konsep diri, pengobatan, kecerdasan emosi, dan lingkungan.
\end{abstract}

Kata Kunci: Perkembangan Emosional; ADHD; Stimulus

\begin{abstract}
Emotional development of children with special needs hyperactive and concentration disorder occurs into early childhood which affect to their difficulties on learning process in classroom. The emotional development relates to the disorder because emotion in children cannot be controlled. Positive stimulus should be built to them so that they can understand self concept. The research problems in this study were the children with special needs hyperactive and concentration disorder development in Aisyiyah Kindergarten 33 Surabaya. This study aimed to describe the developmental aspects mainly in children's emotion. The method used was descriptive qualitative which explained through words and sentences descriptively. The data collections technique used were observation, interview, and documentation. The research objects were children with special needs hyperactive and concentration disorder (ADHD). The results showed that the emotional development of children with special needs hyperactive and concentration disorder (ADHD) affected to their condition so that they had lack understanding to their emotion such as showing too much expression of happiness, angriness, and sadness. This condition was caused by many factors founded like maturity, parenting, self concept, therapy, emotional quotient, and neighborhood.
\end{abstract}

\section{PENDAHULUAN}

Pendidikan anak usia dini sendiri bertujuan untuk mewujudkan suasana belajar dan proses pembelajaran kepada anak secara aktif dan kreatif agar memiliki kecerdasan emosional dan spiritual, serta kecerdasan intelektual yang akan berguna untuk dirinya kelak. Perkembangan anak usia dini sangat dipengaruhi oleh stimulasi yang diberikan oleh orang tua maupun 
pendidik. Stimulasi yang positif akan memberikan dampak yang baik terhadap tumbuh-kembang anak usia dini. Stimulus yang digunakan dapat berupa aktivitas bermain yang merupakan dunia anak untuk mengeksplor lingkungan sekitarnya. Bermain adalah hal yang membuat anak senang sehingga ia mendapatkan pengalaman melalui bermain dan mengamati melalui penginderaan. Pengalaman bermain ini akan tersimpan di jaringan otak anak yang memiliki banyak sekali jaringan yang saling tersambung untuk membentuk ingatan jangka panjang. Jaringan otak yang dikembangkan dengan stimulasi akan berbeda dengan jaringan otak yang tidak mendapatkan stimulasi. Anak menyukai dunianya yaitu bermain, karena dengan bermain anak mendapatkan haknya untuk terpenuhinya kebutuhan psikologi anak. Masa-masa kanak-kanak harus dilalui anak dengan kesenangan yang dapat menciptakan perasaan bahagia. Bermain merupakan suatu keharusan dalam masa ini karena dengan bermain anak dapat mengeksplorasi lingkungannya dan memahami lingkungannya. Pada tahapan usianya anak memiliki tahapan perkembangan yang harus dibnetuk sesuai dengan pola asuh yang benar. Perkembangan aspek-aspek yang harus di optimalkan terdiri dari 6 aspek salah satunya adalah perkembangan emosional.

Interaksi anak usia dini saat memasuki jenjang sekolah taman kanak-kanak yang merupakan awal anak mengenal teman sebayanya dan lingkungannya sehingga timbulnya rasa takut maupun ada yang mudah beradaptasi. Perkembangan emosional ini perlu adanya pembiasaan untuk melatih emosional anak sehingga ketika ia berada di lingkungan keluarga ia mudah untuk mengenal dan memahami saat berada di lingkungan sekolah. Dunia anak ketika proses pembelajaran yang menarik minat anak untuk aktif dalam kegiatan yang bertujuan mengembangkan beberapa aspek terutama aspek sosial emosional anak. Pada dasarnya anak sangatlah rentan emosinya sehngga saat problematika di rumah sampai terbawa saat di lingkungan sekolah. Lingkungan keluarga jauh lebih mendominasi perkembangan emosional, namun saat di lingkungan taman kanak-kanak anak belajar bersama teman sebayanya dan mengembangkan berbagai aspek seperti aspek emosional. Perkembangan emosional anak harus di bentuk semaksimal mungkin untuk mencapai tahapan perkembangan. Mengembangkan emosi yang positif perlu adanya media yang menggugah anak untuk aktif dan mengeksplor lingkungan sekitarnya bersama teman sebayanya. Problematika yang terjadi pada anak usia dini begitu kompeks sehingga adanya pendidik dan orang tua saling bekerja sama untuk mendidik dan menstimulus anak sehingga perkembangan emosional 
anak dapat dilalui dengan baik. Mengembangkan perkembangan emosional ini didasarkan pada pembiasaan yang menjadikan anak terbiasa untuk menumbuhkan emosi yang positif karena pada masa anak ini ibarat spons yang mudah menyerap pengetahuan dan rangsangan.

Menurut Isnanto (2012:25) pada lingkungan sekolah anak berkebutuhan khusus hiperaktif dan gangguan konsentrasi yang dapat disingkat menjadi ADHD (Attention Dificit Hyperactivity Disorder) adalah gangguan perkembangan dalam peningkatan aktivitas motorik anak-anak hingga menyebabkan aktivitas anak-anak yang tidak lazim dan cenderung berlebihan. Hal ini ditandai dengan berbagai keluhan perasaan gelisah, tidak bisa diam, tidak bisa duduk dengan tenang, dan selalu meninggalkan keadaan yang tetap. Kondisi seperti ini harus segera di tangani oleh orang tua, pendidik maupun terapis untuk tetap memberikan stimulasi terhadap anak yang mengalami gangguan. Anak seperti ini cenderung melakukan sesuatu hal semaunya dan sesuka hatinya dan perlu adanya kontrol dari orang dewasa agar perilaku yang nampak terarah dengan baik. Interaksi anak berkebutuhan khusus pada aspek emosionalnya terhadap lingkungannya perlu di latih dengan semaksimal mungkin. Gangguan hiperaktif dan konsentrasi ini membuat anak lebih aktif dari anak normal untuk melakukan sebuah hal yang menguras energinya. Pada saat aktivitas yang membuat anak tertarik untuk ikut aktif di dalam kegiatan tersebut namun, pada setiap aktivitas anak cenderung cepat untuk bosan dan berganti dengan aktivitas lain. Pada dasarnya anak menyukai bermain namun ketika anak-anak di hadapkan pada hal yang berkaitan dengan emosi anak menjadi tidak terkendali dalam beberapa waktu.

Respon dalam menunjukkan emosi yang tepat anak masih perlu banyak bimbingan dan rangsangan karena adanya gangguan ini maka anak akan memiliki perilaku semaunya dan tindakan yang tidak terduga-duga. Anak yang seharusnya dapat berkembang seperti anak normal namun karena kondisi ini anak menjadi tidak ada kontrol yang membuat dirinya dapat menyesuaikan bentuk bentuk emosi. Emosi yang terjadi pada anak yaitu tertawa, kemarahan, dan kekecewaan yang lebih dominan dari ekspresi lainnya. Pada saat mengekspresikan emosinya anak berlebihan sehingga membuat pembelajaran di kelas menjadi tidak kondusif. Energi yang dimiliki anak berkebutuhan khusus hiperaktif dan gangguan konsentrasi ini sangat banyak sehingga gerak yang dilakukan anak membutuhkan waktu untuk membuat perhatiannya terfokus saat proses pembelajaran. Emosi yang memiliki peranan dalam pengolahan reaksi-reaksi yang memiliki berbagai macam perasaanperasaan yang sangat mudah mempengaruhi kinerja otak untuk menyampaikan pada reserptor untuk dapat ditunjukkan melalui 
penginderaan. Perkembangan emosi yang ditunjukkan anak yaitu ketika mengatur emosi tertawa dan marah anak akan mengekspresikannya dengan berlebihan saat tidak ada hal yang membuat situasi di kelas untuk tertawa. Kondisi ini membuat anakanak normal terganggu karena emosi anak yang ditunjukkan secara berlebihan dengan tertawa sendiri saat pembelajaran sedang berlangsung. Perilaku-perilaku yang tampak pada anak tersebut menjadikan anak sulit mengendalikan emosi pada dirinya. Emosi dirinya diekspresikan senang yang berlebihan, kekecewaan yang dapat digambarkan melalui ekspresi wajah dan kemarahan yang muncul secara berlebihan.Adapun tujuan penelitian ini adalah untuk mengetahui perkembangan emosional anak berkebutuhan khusus hiperaktif dan gangguan konsentrasi (ADHD).

\section{HASIL PENELITIAN}

Pada penelitian ini dapat diperoleh hasil penelitian yang dilakukan

\section{METODE PENELITIAN}

Metode penelitian yang digunakan dalam penelitian ini adalah dengan menggunakan metode penelitian kulitatif. penelitian kualitatif bertujuan untuk mendapatkan pemahaman yang lebih luas dan mendalam terhadap fenomena tertentu yang dialami subjek dengan cara mendeskripsikannya dalam bentuk kata-kata yang memiliki makna pada penelitiannya, serta penelitian ini bersifat mengembangkan sebuah teori yang ada untuk dikaji ulang dalam sebuah penelitian.

Teknik untuk memperoleh data yang dimaksud peneliti menggunakan teknik dan prosedur pengumpulan data, berupa observasi, wawancara dan dokumentasi. Adapun teknik pengumpulan data yang menjadi pedoman peneliti sebagai berikut:

melalui penilaian yang terjadi di lapangan sebagai berikut 


\section{Rubrik Indikator}

\begin{tabular}{|c|c|c|c|c|c|c|}
\hline \multirow{2}{*}{ No. } & Aspek Perkembangan & \multicolumn{4}{|c|}{ Skala Nilai } & \multirow{2}{*}{ Keterangan } \\
\hline & $\begin{array}{lll}\text { Perkembangan } & \text { Emosional } & \text { Anak } \\
\text { ADHD } & & \\
\end{array}$ & 1 & 2 & 3 & 4 & \\
\hline 1. & $\begin{array}{l}\text { Anak mampu mengendalikan emosi } \\
\text { pada dirinya }\end{array}$ & & $\sqrt{ }$ & & & \\
\hline 2. & $\begin{array}{lcc}\text { Anak mampu untuk tidak } \\
\text { mengekspresikan kesedihannya }\end{array}$ & & & $\sqrt{ }$ & & \\
\hline 3. & $\begin{array}{l}\text { Anak mampu untuktidak menganggu } \\
\text { temannya }\end{array}$ & & $\sqrt{ }$ & & & \\
\hline 4. & $\begin{array}{l}\text { Anak mampu menunjukkan berbagai } \\
\text { ekspresi (senang, marah, sedih, } \\
\text { kecewa, ketakutan) }\end{array}$ & & $\sqrt{ }$ & & & \\
\hline \multicolumn{2}{|c|}{$\begin{array}{l}\text { Adapun indikator yang menjadi tolak } \\
\text { ukur pada penelitian, sebagai berikut: } \\
\text { a. Anak mampu mengendalikan } \\
\text { emosi pada dirinya }\end{array}$} & & \multicolumn{4}{|c|}{$\begin{array}{l}\text { menggangu temannya deng } \\
\text { menjaili temannya deng } \\
\text { bersembunyi di kolong me } \\
\text { (LO3, CW7, D4). }\end{array}$} \\
\hline
\end{tabular}

Ananda dafa saat berada di lingkungan sekolah masih belum mampu untuk mengendalikan emosi pada dirinya saat berada di lingkungan sekolah (LO1, CW8, D3). Saat bercengkrama dengan teman-temannya ananda cenderung menganggu temannya dan mudah tersulut emosi saat berinteraksi dengan temannya di kelas (LO3, CW9, D5).

b. Anak mampu untuk tidak mengekspresikan kesedihannya Ananda dafa terlihat sering tertawa sendiri daripada memperlihatkan ekspresi

d. Anak mampu menunjukkan berbagai ekspresi (senang, marah, sedih, kecewa, ketakutan)

Ananda dafa sangat mudah menunjukkan berbagai ekspresi saat di sekolah, seperti pada saat aktivitas berdoa ananda cenderung masuk ke dunianya sendiri dengan tertawa sendiri secara berlebihan dengan menunjukan pada guru yang sedang mengajar sehingga menggangu proses pembelajaran di kelas (LO4, CW10, D2).

kesedihannya (LO2, CW6, D1)

c. Anak mampu untuk tidak menganggu temannya

Ananda dafa saat berada di lingkungan sekolah ananda cenderung menggangu temannya yang berada di dekat temannya, terkadang ananda juga

Perkembangan emosional anak mempengaruhi kondisi anak yang mengalami gangguan hiperaktif dan gangguan konsentrasi (ADHD) sehingga memerlukan pengarahan dan stimulus yang dapat membuat anak memahami konsep diri maupun 
orang lain. Berdasarkan hasil penelitian yang dapat diambil dari penilaian yang terjadi pada proses pembelajaran sehingga mempermudah proses pengujian hasil melalui teknik triangulasi sebagai berikut:

Triangulasi

\begin{tabular}{|c|c|c|c|c|}
\hline No & Butir-butir & $\begin{array}{c}\text { Lembar } \\
\text { Observasi } \\
\text { (LO) }\end{array}$ & $\begin{array}{c}\text { Catatan } \\
\text { Wawancara } \\
(\mathrm{CW})\end{array}$ & $\begin{array}{l}\text { Dokumentasi } \\
\text { (D) }\end{array}$ \\
\hline 1. & $\begin{array}{l}\text { Anak mampu } \\
\text { mengendalikan emosi } \\
\text { pada dirinya }\end{array}$ & $\begin{array}{l}\text { LO1,LO8,LO } \\
\text { 7,LO4 }\end{array}$ & CW8, & $\begin{array}{l}\text { D3,D6,D7, } \\
\text { D3.1 }\end{array}$ \\
\hline 2. & $\begin{array}{l}\text { Anak mampu untuk } \\
\text { tidak mengekspresikan } \\
\text { kesedihannya }\end{array}$ & $\begin{array}{c}\text { LO2,LO4,LO } \\
5\end{array}$ & CW6 & $\begin{array}{c}\text { D1,D8,D9,D } \\
10\end{array}$ \\
\hline 3. & $\begin{array}{l}\text { Anak mampu untuk tidak } \\
\text { menganggu temannya }\end{array}$ & $\begin{array}{c}\text { LO3,LO6,LO } \\
\text { 9,LO1 }\end{array}$ & CW7, CW9 & $\begin{array}{c}\mathrm{D} 4, \\
\mathrm{D} 4.1, \mathrm{D} 5, \mathrm{D} 10 \\
.1, \mathrm{D} 11, \mathrm{D} 13\end{array}$ \\
\hline 4. & $\begin{array}{l}\text { Anak mampu } \\
\text { menunjukkan berbagai } \\
\text { ekspresi (senang, marah, } \\
\text { sedih, kecewa, } \\
\text { ketakutan) }\end{array}$ & LO4,L07,L09 & CW10 & $\begin{array}{c}\text { D2,D2.1,D12 } \\
\text {,D14 }\end{array}$ \\
\hline
\end{tabular}

\section{PEMBAHASAN}

Perkembangan emosional anak berkebutuhan khusus hiperaktif dan gangguan konsentrasi akan selalu berkaitan dengan kegiatan anak saat di sekolah.Perkembangan emosi pada anak yang mengalami hiperaktif dan gangguan konsentrasi akan terjadi disaat anak sudah teralihkan pada hal lain. Ketidakstabilan emosi ini mempengaruhi proses pembelajaran sehingga anak terlihat kesulitan dalam belajar. Pada saat guru memberikan instruksi pada anak untuk mengikuti gerakan menyanyi anak akan mengikuti namun, hanya beberapa menit saja anak dapat melakukan gerakan tepuk tangan. Anak juga sering tertawa sendiri dan sibuk dengan dunianya. Berdasarkan penjelasan paparan di atas, berkaitan dengan Santoso (2012:97) bahwa karakteristik anak berkebutuhan khusus hiperaktif dan gangguan konsentrasi ini menunjukkan perilaku impulsif, dan sering melupakan informasi dari guru 
maupun barang-barangnya sendiri. Perkembangan emosional anak berkebutuhan khusus hiperaktif dan gangguan konsentrasi akan selalu beriringan karena adanya syaraf otak yang mempengaruhi kondisi psikologis anak sehingga akan berpengaruh pada perilaku. Perkembangan yang dicapai anak selama proses pembelajaran anak mampu mengendalikan emosi pada drinya, pengamatan yang dilakukan oleh peneliti ditemukan bahwa anak belum mampu mengendalikan emosi pada dirinya, berdasarkan pengamatan di lapangan anak cenderung menunjukkan melalui kemarahan yang berlebihan padahal temannya hanya mengajak bermain sehingga pengendalian diri pada anak kurang terkendali sehingga sangat mudah tersulut emosi yang tidak stabil. Pada pencapaian aktivitas di kelas anak tidak mengekspresikan kesedihannya sehingga ekspresi ini jarang muncul pada saat pembelajaran, walaupun saat peristiwa yang membuat anak mengekspresikan hal ini. Namun, ananda cenderung menampakkan suatu ekspresi yang berlebihan yang tidak biasa dialami anak seumuran yaitu dengan mengalikan hal lain serta masuk ke dunianya sendiri. Pada pembahasan teori mengenai anak berkebutuhan khusus hiperaktif dan gangguan konsentrasi (ADHD) ini dapat membuat anak menjadi kurang perhatian dan tidak bisa duduk diam di tempat duduknya sehingga guru menjadi kesulitan dalam mengatasi emosi yang masih labil dan belum bisa dikendalikan oleh guru sehingga saat proses pembelajaran masih belum maksimal. Perkembangan emosional anak berkebutuhan khusus hiperaktif dan gangguan konsentrasi (ADHD) ini harus di stimulus untuk dapat mengendalikan emosi sesuai dengan tahapannya.

Interaksi dengan teman sebayanya memang terjalin, namun di sisi lain anak cenderung menggangu temannya yang sedang mendengarkan guru ketika mengajar, sehingga temannya terganggu karna ulah anak. Saat anak-anak mengerjakan tugas dari guru, ada perilaku yang aneh pada Dafa yaitu masuk di kolong meja yang berwarna hijau dan menjaili kaki temantemannya. Pada saat sikap anak dalam proses pembelajaran sangat mudah bagi anak untuk mengekspresikan emosi tertawa sendiri secara berlebihan dan anak cenderung lebih terfokus pada dunianya sendiri. Proses pembelajaran berlangsung terkadang anak cenderung menertawai guru maupun temannya saat tidak ada hal yang lucu pada saat itu. Menurut Erikson dalam Hapsari (2016:231) usia prasekolah anak terdorong untuk melakukan tindakan atau memiliki inisiatif untuk melakukan suatu tindakan yang diinginkan, namun anak belajar jika tindakannya ada yang harus sesuai dengan stanndar perilaku yang ada atau bebas berekspresi. Pada saat dilakukannya penelitian mengenai kestabilan emosi 
anak dalam melakukan setiap aktivitas ditemukan beberapa ekspresi pada anak. Perkembangan emosional anak berkebutuhan khusus hiperaktif dan gangguan konsentrasi (ADHD), berdasarkan hasil pengamatan dipengaruhi oleh beberapa faktor diantaranya faktor kematangan, pola asuh, konsep diri, pengobatan, kecerdasan emosi, dan lingkungan. Pekembangan emosional anak sangat berkaitan dengan kondisi anak yang mengalami hiperaktif dan gangguan konsentrasi yang memiliki kecendrungan dalam perilaku maupun tindakan kesehariannya. Anak menunjukkan ekspresi senang yang sangat berlebihan sehingga anak tidak dapat mengendalikan emosi pada dirinya. Pada saat aktivitas yang dilakukan anak kesulitan dalam proses belajar karna adanya gangguan tidak bisa diam, tidak fokus, kurang perhatian yang sangat menganggu kondisi anak dalam menerima berbagai informasi dari guru maupun temannya. kesulitan dalam belajar akan berdampak pada tugas yang diberikan guru tidak terselesaikan. Emosi yang terjadi pada anak yang mengalami gangguan ini dapat berubah dengan sangat signifikan seperti saat anak marah maupun senang pada lingkungan di sekolah.Pendekatan pada anak ini harus sangat intens yang mana melalui pendekatan inilah anak dapat belajar memahami pengolahan emosi dalam diri

\section{KESIMPULAN}

Dari hasil penelitian ini dapat diambil kesimpulan yaitu perkembangan emosional anak masih belum stabil sehingga konsep dalam diri anak belum terbentuk karena adanya gangguan yang dialami anak membuat kurangnya pemahaman tentang ekspresi yang harus ditunjukkaan pada saat berinteraksi di lingkungan sekolah. Pada saat proses pembelajaran anak akan menunjukkan ekspresi tertawa dan kemarahan yang berlebihan sehingga adanya pengendalian terhadap emosi anak. Gangguan yang terjadi pada anak akan sangat berpengaruh pada perkembangan emosi anak karena pada tahapan perkembangan ini anak belajar untuk berinteraksi dengan teman sebayanya. Interaksi yang dibangun anak pada aspek perkembangan menjadi tolak ukur untuk anak bersosialisasi dengan lingkungan sekitarnya. Kemampuan anak dalam mengekspresikan ekspresi yang sangat berlebihan yang menjadikan anak kurang dapat memahami dirinya untuk memahami lingkungan sekitarnya. Peranan emosi pada anak ini menjadi tolak ukur untuk anak yang mengekspresikan mimik wajah bahagia, kemarahan dan kekecewaan yang membuat anak melakukan perilaku-perilaku yang membuat lingkungan kelas menjadi kurang kondusif karena adanya ekspresi yang sangat berlebihan. Anak berkebutuhan khusus hiperaktif dan gangguan konsentrasi ini mengalami kesulitan dalam pengelolaan emosi 
yang harus diekspresikan terhadap rangsangan yang diberikan guru saat proses pembelajaran di kelas sehingga terjadinya ketidakstabilan yang membuat anak menjadi labil. Pemahaman emosi pada diri anak memang tidak mudah, namun awal dari pengendalian emosi yaitu mampu mengenali ekspresi diri sehingga anak dapat memahami emosi sesuai dengan tahapan usia. Emosi dibentuk dari kematangan anak dalam memahami konsep diri, sehingga pembekalan emosi sejak dini sehingga anak akan mampu mengenali emosi dalam dirinya. Agar dapat mengembangkan pemahaman pada sisi psikologis anak agar anak tumbuh dan berkembang sesuai dengan harapan. Penangganan pada kesulitan belajar dapat menjadi bahan untuk memberikan stimulus yang sesuai dengan tahap perkembangan pada anak.

\section{DAFTAR PUSTAKA}

Hapsari,Indri,Iriana. (2016). Psikologi Perkembanagan Anak.Cetakan Pertama. Kembangan-Jakarta Barat: Permata Puri Media.

Hurlock, ElizabethB.(1978).

Psikologi Perkembangan. Edisi Kelima. Jakarta: Erlangga.

Isnanto, Yuli. (2012). Mendidik Anak $A D D$ (Attention Deficit Disorder). Jogjakarta: Javalitera: Perpustakaan Nasional: Katalog Dalam terbitan (KDT).
Santoso,Hargio. (2012). Cara Memahami dan Mendidik Anak Berkebutuhan Khusus.Cetakan Pertama. Yogyakarta: Gosyen Publishing. 